\title{
Pesticide fate modeling in conservation tillage: simulating the effect of mulch and cover crop on S-metolachlor leaching
}

Jesús M. Marín-Benito ${ }^{\mathrm{a}, \mathrm{c}, *}$, Lionel Alletto ${ }^{\mathrm{b}, \mathrm{d}}$, Enrique Barriuso ${ }^{\text {a }}$, Carole Bedos ${ }^{\text {a }}$, Pierre Benoit $^{\text {a }}$, Valérie Pot ${ }^{\mathrm{a}}$, Laure Mamy ${ }^{\mathrm{a}}$

${ }^{\text {a }}$ UMR ECOSYS, INRA, AgroParisTech, Université Paris-Saclay, 78850 Thiverval-Grignon, France

${ }^{\mathrm{b}}$ UMR AGIR, Université de Toulouse, INRA, INPT, 31326 Castanet Tolosan, France

${ }^{\mathrm{c}}$ Current address, IRNASA-CSIC, 40-52 Cordel de Merinas, 37008 Salamanca, Spain

${ }^{\mathrm{d}}$ Current address, Chambre Régionale d'Agriculture Occitanie, 31326 Castanet-Tolosan Cedex, France

*Corresponding author at: IRNASA-CSIC, 40-52 Cordel de Merinas, 37008 Salamanca, Spain. E-mail address: jesusm.marin@irnasa.csic.es (J.M. Marín-Benito)

\section{Author's e-mails:}

Jesús M Marín-Benito: jesusm.marin@irnasa.csic.es

Lionel Alletto: lionel.alletto@occitanie.chambagri.fr

Enrique Barriuso: enrique.barriuso@inra.fr

Carole Bedos: carole.bedos@inra.fr

Pierre Benoit: pierre.benoit@inra.fr

Valérie Pot: valerie.pot@inra.fr

Laure Mamy: laure.mamy@inra.fr 


\section{ABSTRACT}

2 Conservation tillage practices mainly based on cover crops and no-tillage with

3 accumulation of crop residues at the soil surface (mulch) modify the environmental fate

4 of pesticides. However, only few pesticide fate models are able to consider mulch of

5 crop residues as well as the effect of intermediate cover crops. Thus, the objective was

6 to develop an approach to model the effects of crop residues left at the soil surface and

7 cover crops on the fate of pesticides. This approach consisted in (1) considering the crop

8 residues as a soil layer with specific physical, hydrodynamic and pesticide-reactivity

9 properties close to that of a high organic content soil layer, and (2) introducing a

10 correction factor of the potential evapotranspiration, estimated through a calibration

11 step, to take into account the reduction of soil evaporation by the presence of a mulch.

12 This approach was developed using MACRO as support pesticide model. To assess the

13 model performances, we used the data from a field experiment designed in an irrigated

14 maize monoculture under conservation tillage. Soil water content, water percolates, soil

15 temperature and S-metolachlor herbicide concentrations in the leachate at $1 \mathrm{~m}$ depth

16 were measured during two years. The approach chosen to simulate the mulch effects

17 allowed MACRO to make acceptable predictions of the observed water percolation, soil

18 temperature and to a less extent herbicide leaching. However, it showed a poor

19 performance to simulate the soil water content. Results are discussed in terms of further

20 modeling options to better assess the environmental risks of pesticides under

21 conservation tillage. This approach remains to be tested against various soils, crops,

22 pesticides and types of mulch.

25 Keywords: 
Pesticide fate model

27 MACRO

28 Crop residue

29 Cover crop

30 Field experiment

$31 \quad$ Pesticide

\section{Introduction}

Conservation tillage systems are mainly characterized by no-tillage, accumulation of harvested crop residues as mulch on the soil surface as well as presence of cover crops during the fallow period. These cropping systems are interesting alternatives to conventional systems having many benefits on the soil protection and crop productivity (Hartwig and Ammon, 2002; Thierfelder et al., 2013; Trail et al., 40 2016).

Crop residues left at the soil surface allow reduction of surface runoff and soil erosion (Prosdocimi et al., 2016), regulation of the soil surface temperature (Alletto et al., 2011), capture of rainfall water (Iqbal et al., 2013), increase in soil water content by reducing the evaporation from the soil surface (Dahiya et al., 2007), control of weeds (Martins et al., 2016), and increase in the total organic matter content in the top soil (Castellanos-Navarrete et al., 2012). Cover crops are efficient to reduce nitrate leaching 47 and increase carbon sequestration (Plaza-Bonilla et al., 2016, 2017; Tribouillois et al., 2016) contributing to preserve the groundwater quality and to reduce the impact on the net global warming potential, respectively (Yagioka et al., 2015). 
The fate of pesticides in soil under conservation tillage systems is different from

their fate under conventional system (Alletto et al., 2010). Some studies have shown that no-till enhances pesticide adsorption on soil because of the increase in organic carbon (OC) content but also that the adsorption varies with the nature and/or the degree of decomposition of the crop residues (Alletto et al., 2013; Aslam et al., 2013; Cassigneul et al., 2015). The presence of a mulch can result in increase in pesticide volatilization (Whang et al., 1993) and increase in pesticide persistence because of a decrease of its bioavailability to degrading microorganisms (Cassigneul et al., 2016). However, opposite effects have also been observed. For example, Gan et al. (2003) showed that the degradation rates of the dicamba and 2,4-D herbicides in mulched soils were enhanced because of the increase in soil OC content and in the abundance of microbial degrading population. Regarding volatilization, Bedos et al. (2017) noted a modification of its dynamics and Weber et al. (2006) observed that crop residues helped to maintain high soil humidity, which decreased soil temperature and consequently the volatilization of metolachlor. Concerning cover crops, field studies have evidenced a reduction of pesticide leaching, which was mostly due to modifications of the soil water balance (Alletto et al., 2012).

Models able to take into account the combined effects of crop residues and cover crops on water balance, soil temperature and pesticide fate would be useful tools to assess the environmental impacts of these rising conservation tillage practices. However, very few models are available (Mottes et al., 2014). To simulate the soil water dynamic under a mulch of crop residues using the Hydrus 1-D model (Simunek et al., 2005), Singh et al. (2011) replaced the crop residue layer by a hydraulically equivalent soil layer, and Dahiya et al. (2007) optimized the potential evaporation rate to take into account the effect of crop residues on the soil water and temperature regimes. However, 
no pesticide was considered in their studies. Recently, Lammoglia et al. (2017) combined STICS (a crop model able to simulate various agricultural practices, Brisson et al., 2009) and MACRO (a pesticide fate model, Larsbo and Jarvis, 2003) to simulate pesticide leaching under different cropping systems. The performance of the resulting STICS-MACRO model was found to be acceptable but it was not tested under mulch conditions. The approach developed by Queyrel et al. (2016) consisted to implement a pesticide-module to STICS, leading to the STICS-Pest model. STICS-Pest was found to be as efficient as other capacity pesticide fate models to predict pesticide leaching in some contexts, however, the main limitation of STICS-Pest is its inability to describe water dynamics in presence of preferential flows or a fluctuating shallow water table because the description of water dynamic is based on a capacity approach. Ghirardello et al. (2010) developed SoilPlus to simulate the fate of non-ionized organic chemicals in the air-litter-soil system. The main features of the model are the double-layered air compartment interacting dynamically with multilayered litter and soil compartments, with seasonal dissolved organic carbon fluxes. However, the water balance is based on a capacity approach. The RZWQM model considers plant residues (as layer of crop residues or other plant materials immediately overlying the surface of the soil) and their effects on pesticides fate (Wauchope et al., 2004). However, none of the four models, PELMO, PRZM, PEARL and MACRO, used for risk assessment for European pesticide registration (FOCUS, 2000) allows to simulate mulch effects. Therefore, the objective of this work was to use MACRO to model the effects of crop residues left at the soil surface and cover crops on the fate of pesticides. The strategy was (1) to consider crop residues as a soil layer having its own hydraulic properties (following the approach of Singh et al., 2011), and pesticide adsorption and degradation coefficients, and (2) to use a correction factor in the calculation of the 
100 potential evapotranspiration to consider the effect of the crop residues on the water

101 balance and consequently on solute movement (following the approach of Dahiya et al.,

102 2007). This work was based on a field experiment monitoring the leaching of the S-

103 metolachlor herbicide in a conservation tillage irrigated maize monoculture cropping

104 system (with cover crops and both maize and cover crop-residue mulch).

105

106 2. Materials and methods

107 2.1. Model description

108 MACRO is a process-based, one-dimensional, dual-porosity model which

109 considers preferential flows by dividing the soil pore space into micropore and

110 macropore domains characterized by different flow rates and solute concentrations

111 (Larsbo and Jarvis, 2003). The boundary between the two domains is defined by a soil

112 water pressure head close to saturation, and its associated water content and hydraulic

113 conductivity. Soil water flow and solute transport in the micropores are described by the

114 Richards' equation and the convection-dispersion equation, respectively. For the

115 macropore domain, water flow is gravity driven and solute transport is assumed to be

116 solely convective. Exchange between the two domains is calculated according to

117 physically based expressions using an effective aggregate half-width. Degradation of

118 pesticides follows first-order kinetic and solute sorption is described using the

119 Freundlich isotherm. The model simulates degradation and sorption processes in both

120 micro- and macropore domains. The effect of soil moisture content and soil temperature

121 on the pesticide degradation rate is also taken into account. Soil temperatures are

122 calculated from air temperatures using the heat conductivity equation. A detailed

123 description of the model can be found in Larsbo and Jarvis (2003). For this work we 
124 used a development version of the MACRO model provided by the MACRO

125 developers, aiming at replacing the official release MACRO 5.2 in the future.

\subsection{Field experiment}

Experimental data came from a field-scale leaching study conducted in Toulouse area (Southwest of France). A conservation tillage maize monoculture cropping system

130 was designed in an experimental plot of $12 \mathrm{~m}$ x $60 \mathrm{~m}$. According to IUSS WRB (2007), 131 the soil is a Stagnic Luvisol with clay-loam texture (Table 1). mixture of oat, phacelia and vetch as intermediate cover crops (2010-2011, 2011-2012

134 and 2012-2013). Residues were left at the soil surface after maize harvest and after

135 cover crop destruction by the glyphosate herbicide. At the end of 2010, the first cover crop was sown after a conventional tillage with a mouldboard plow $(25-28 \mathrm{~cm}$ depth) while a reduced tillage with a working depth $\leq 10 \mathrm{~cm}$ was carried out before sowing the cover crop in 2011 and 2012. A direct seeding into crop residues was systematically

139 done for the maize crop. The resulting crops succession along with the crops

140 development dates are listed in Table 2. Sprinkler irrigation was applied in summer 141 during the maize growing season in events that ranged from 25 to $40 \mathrm{~mm}$ reaching a total water amount of $220 \mathrm{~mm}$ in 2011, and $255 \mathrm{~mm}$ in 2012 (Fig. 1).

144 methylethyl) acetamide] is a selective herbicide used for pre- or post-emergence weed 145 control in crops such as maize, sorghum or soybean. The whole surface of the plot was 146 sprayed once with S-metolachlor at $1.52 \mathrm{~kg}$ a.i./ha as Calibra (Syngenta) formulation on

1473 May 2012 (post-emergence) (49 days after the cover crop destruction and thus after 148 the occurrence of a mulch on the soil). Two percent of the S-metolachlor applied rate 
149 was assumed to be intercepted by the growing maize (Marín-Benito et al., 2014). Prior

150 to the experimentation set up in 2011, the herbicide had never been applied over the 151 experimental plot.

152 Climatic data were collected with a meteorological station located at the field

153 site. Soil water content and temperature were monitored with TDR probes and

154 temperature sensors, respectively, installed at 0.2, 0.5 and $1 \mathrm{~m}$ depth. Water flows were

155 monitored using one tension plate lysimeter with a fixed tension of $-100 \mathrm{hPa}$ installed at

$1561 \mathrm{~m}$ depth in the middle of the experimental plot. Leachates were periodically sampled

157 and kept at $4^{\circ} \mathrm{C}$ until S-metolachlor analyses. The analyses were done by the

158 Laboratoire Départemental d'Analyses de la Drôme (Valence, France) accredited by

159 COFRAC (French Committee of Accreditation). The limit of quantification and the

160 limit of detection were 0.02 and $0.007 \mu \mathrm{g} \mathrm{L}^{-1}$, respectively.

2.3. Model parameterization to take into account the effect of crop residues and cover crops on the fate of pesticide

\subsubsection{Representation of a mulch layer in MACRO and model parameterization}

MACRO was parameterized with all available site-specific data. Parameters that were not measured were either estimated by pedotransfer functions, taken from the literature or set to default values according to the model users manual.

The mulch layer was considered as a porous medium analogous to a $100 \%$-sand soil layer of $5 \mathrm{~cm}$-thickness at the top of the soil (physical description) having

170 hydrodynamic properties corresponding to a high organic soil layer (hydrodynamic description) (Wösten et al., 1999) (Table 1).

The depth of the 1-D soil profile was set to $2 \mathrm{~m}$ and split into four horizons of

173 different thicknesses (Table 1). Van Genuchten's soil-water retention parameters $\left(\theta_{\mathrm{s}}, \alpha\right.$ 
174 and $\mathrm{n}$ ) and the tortuosity factor in micropores (ZM) were calculated using the

175 pedotransfer functions reported by Wösten et al. (1999), while the residual soil water 176 content parameter $\left(\theta_{\mathrm{r}}\right)$ was set to 0.01 . The soil water content at wilting point was

177 estimated from the water retention curves $\left(\theta_{\mathrm{WP}}, \mathrm{pF}=4.2\right)$ and the saturated hydraulic 178 conductivity values $\left(\mathrm{K}_{\mathrm{sat}}\right)$ from tension infiltrometer measurements made for the soil 179 profile $(0-100 \mathrm{~cm})($ Table 1$)$.

180 The soil characteristics of the macropore domain were chosen as follows: the 181 boundary soil water pressure head between micro and macropores was set to default 182 values $(\mathrm{CTEN}=10 \mathrm{~cm})$, and the water content corresponding to this boundary soil water 183 pressure head $\left(\theta_{\mathrm{b}}\right)$ was calculated from the water retention curves (Table 1$)$. The pore 184 size distribution index in the macropores (ZN) was determined following the 185 recommendations of Beulke et al. (2002). On the other hand, the boundary hydraulic 186 conductivity $\left(\mathrm{K}_{\mathrm{b}}\right)$ in the soil profile, and the parameter which controls the exchange of 187 both water and solute between the micropore and macropore flows (ASCALE) were 188 estimated with the pedotransfer functions included in MACRO 5.2 (Moeys et al., 2012). 189 Given the lack of data in the literature for these macropore domain parameters 190 corresponding to crop residues, similar values were used for the mulch layer than for the 191 first soil horizon (Table 1).

192 Topsoil and mulch S-metolachlor sorption $\left(\mathrm{K}_{\mathrm{d}}\right)$ and degradation $\left(\mathrm{DT}_{50}\right)$ 193 parameters were obtained from laboratory experiments on soil, oat and vetch residues

194 (after 56 days of decomposition) and/or on soil+oat and vetch residues (Table 3). The $195 K_{d}$ values for deeper soil layers were estimated assuming this coefficient was 196 proportional to OC content (Marín-Benito et al., 2014) while the variation of $\mathrm{DT}_{50}$ with 197 depth was calculated according to the recommendations of FOCUS (2000) (Table 3). 
199 reference evapotranspiration used for the simulations were measured using the 200 meteorological station aforementioned.

\subsubsection{Modelling the effect of the mulch layer and cover crops on the water balance}

Crop residues have a direct effect on heat and water transfer in the soil profile and they indirectly reduce the soil evaporation (Khaledian et al., 2012). Under frequent rainfall or irrigation events, the crop residues evaporate the stored water (Findeling, 2001) and thus decrease the temperature at the soil surface creating a micro-climate around the mulch with reduced global climatic demand. To represent this micro-climate, we introduced an empirical correction factor $\left(k_{m}\right)$ to decrease the potential evapotranspiration (ETP) for periods when crop residues were present, modifying the global climatic demand (Khaledian et al., 2012). The ETP in the presence of mulch

$211\left(\mathrm{ETP}_{\mathrm{m}}\right)$ was thus calculated by applying a crop factor $\left(k_{c}\right)$ and the correction factor $\left(k_{m}\right)$

212 to the reference evapotranspiration data $\left(\mathrm{ET}_{0}\right)$ as indicated in equation [1]:

$213 \quad \operatorname{ETP}_{m}=\left(E T_{0} \times k_{c}\right) \times k_{m}$

214 The $k_{c}$ values were taken from FOCUS (2000) for maize and cover crops (considered as

215 winter cereals), and the $k_{m}$ values were determined according to a two-step 216 parameterization as follows.

217 In the first step (Step 1), two $k_{m}$ values (non-optimized $k_{m}$ values) were fixed, 218 one for each cropping period: the cover crop growth and the maize growth under cover 219 crop mulch (CC residues) (Fig. 2). We assumed: (1) no reduction in evaporation $\left(k_{m}=1\right.$ 220 in Eq. 1) during the growth of the cover crop, (2) a constant reduction in evaporation $221 \quad\left(k_{m}<1\right.$ in Eq. 1) after the destruction of the cover crop (5 April 2011 and 15 March 2012) and during the maize seasons until the emergence date of the new cover crop cycle (20 
223 October 2011 and 7 October 2012) due to the presence of $\mathrm{CC}$ residues. We assigned a

224 value of 0.84 to $k_{m}$ based on the study of Khaledian et al. (2012).

In the second step (Step 2), $k_{m}$ values were optimized by calibration for each crop, maize and cover crop, by fitting the simulated water percolated volumes to the measured ones. This calibration step allowed to consider the effects of different crop development stages, amounts of irrigation and thus of water stored in the crop residues, year period, amount of crop residues and/or degree of mulch decomposition, among others, that participate to the reduction of the global climatic demand caused by the crop residues (Abu-Awwad, 1999; Alletto et al., 2011; Chen et al., 2007; Lascano and Baumhardt, 1996; Li et al., 2008). Therefore, different $k_{m}$ values were estimated for the total simulation period (Fig. 2). For maize, a lower value of $k_{m}$ was assigned to the first part of its growing period than to the second part in order to account for the effect of decomposition of $\mathrm{CC}$ residues on mulch thickness. For cover crops, $k_{m}$ remained equal to 1 (Fig. 2).

\subsubsection{Crop parameterization}

Crop parameters that were not measured, such as LAI, root depth and root distribution at the different development stages (emergence, flowering and harvest dates) were taken from Marín-Benito et al. (2014) for maize and from the FOCUS

242 Châteaudun scenario (FOCUS, 2000) for cover crops (oat with phacelia and vetch 243 crops) considered as winter cereals (see 2.2, Table 2). Indeed, the emergence and 244 harvest dates observed in the experimental site for winter cereals and the climatic conditions (rain and temperature) were similar to those of Châteaudun scenario allowing assumption of similar crop development. 


\subsubsection{Simulation conditions}

To minimize the impact of the initial conditions on the results, and given that temperature and soil moisture measurements were not available at the beginning of the experiment along the soil profile, a warm up period of 3 months previous to the first crop period was used to initialize the simulations (Marín-Benito et al., 2014). Hydrostatic pressure equilibrium was thus initially considered in the soil profile. A constant hydraulic gradient equal to 1 was assumed for the bottom boundary condition since the groundwater level was always below $2 \mathrm{~m}$ depth during the simulation period. Simulations were run from 10 July 2010 to 31 December 2012.

\subsection{Evaluation of model performance}

The performance of MACRO was assessed using three statistical indices: the modelling efficiency $(E F)$, the coefficient of residual mass $(C R M)$, and the Pearson to the following equations:

$$
E F=1-\left[\sum_{i=1}^{n}\left(S_{i}-O_{i}\right)^{2} / \sum_{i=1}^{n}\left(O_{i}-O_{m}\right)^{2}\right]
$$

$C R M=\left(\sum_{i=1}^{n} O_{i}-\sum_{i=1}^{n} S_{i}\right) / \sum_{i=1}^{n} O_{i}$

$r=\sum_{i=1}^{n}\left(O_{i}-O_{m}\right) \times\left(S_{i}-S_{m}\right) /\left[\sum_{i=1}^{n}\left(O_{i}-O_{m}\right)^{2}\right]^{1 / 2} \times\left[\sum_{i=1}^{n}\left(S_{i}-S_{m}\right)^{2}\right]^{1 / 2}$

where $O_{i}$ and $S_{i}$ are the observed and simulated values, respectively, $O_{m}$ and $S_{m}$ are the mean observed and simulated values respectively, and $n$ is the number of sampling dates. The optimum value of $E F$ and $r$ is +1 , and that of $C R M$ is zero. If $C R M>0$, then there is an underestimation of observed values, and an overestimation if $C R M<0$. 


\section{Results}

273

274

275

276

277

278

279

280

281

282

283

284

285

286

287

288

289

290

291

292

293

294

295

296

\subsection{Modelling soil temperature}

Because pesticide degradation rate depends on temperature, correct simulation of the soil temperature along the soil profile is critical. MACRO simulated very well the soil temperature (Fig. 3): $E F>0.90, r>0.89$, and $C R M$ ranged from 0 to 0.01 (Table 4), without any modification of parameterization regarding the potential effects of crop residues on soil temperature.

\subsection{Modelling soil water content}

When no $k_{m}$ factor was considered for ETP calculation, the soil water content was generally overestimated by the model at the three different depths during the second cover crop cycle (CC-2) and during the non-irrigated period of the second maize crop cycle (Maize-2) (until 20 June 2012) (Fig. 4). Then, the soil water content along the soil profile was underestimated from the irrigated period of Maize-2 to the emergence of the third cover crops (CC-3) at the end of October 2012 when MACRO overestimated again the soil water content (Fig. 4). The underestimation simulated during the irrigated period of Maize- 2 was mainly observed at $0.2 \mathrm{~m}$ depth and it disappeared with depth suggesting a decrease in the effect of the crop residues on soil moisture at lower depths (Fig. 4) (Bussière and Cellier, 1994).

When the fixed $k_{m}$ value of 0.84 (Khaledian et al., 2012) was used for each maize cycle (Step 1) to account for the crop residues effect on evapotranspiration during the maize growth, the simulation of soil water content at the different soil depths was partially improved (Fig. 4). When considering the whole cropping period of Maize-2, a significant increase in $E F$ was obtained for the soil water content at $0.2 \mathrm{~m}$ depth $(E F=0.21)$ but not at 0.5 and $1 \mathrm{~m}$ depth (Table 4$)$. Similarly, when only considering the 
297 irrigated period of Maize-2 season after 20 June of 2012, simulation of soil water

298 content at $0.2 \mathrm{~m}$ was improved compared to the simulation without $k_{m}$ (Table 4 , higher $299 E F$ and lower $C R M)$. The $r$ values increased for both the whole period and the irrigated

300 period of Maize-2 at the different soil depths after the application of the fixed $k_{m}$ value

301 (Table 4).

302 Calibrating the ETP correction factor for each growing period (Step 2) improved

303 the modelling of soil water content after the 20 June of 2012, but it remained poor when

304 considering the whole cropping period $(\mathrm{EF}<0, \mathrm{r}<0.53)$ (Fig. 4, Table 4). However, the

305 measured soil water content was only slightly overestimated as indicated by the

306 negative $C R M$ values close to $0(-0.07<C R M<-0.04)$. The low EF values were

307 strongly conditioned firstly by the noisy measured data and secondly by the large

308 overestimation of soil water content simulated before 20 May 2012 (Fig. 4). The three

309 statistical indices were therefore improved $(-0.20<E F<0.21,-0.03<\mathrm{CRM}<0.03$,

$3100.58<r<0.61)$ when they were calculated for the second cropping period, from 20

311 June 2012 (beginning of the irrigated period of Maize-2) to the end of simulation (Table

$3124)$.

313

\subsection{Modelling water percolation}

Without modifying the ETP by the $k_{m}$ factor, MACRO underestimated the

316 volume of water measured in the lysimeter, except on 17 December 2012 when it was

317 overestimated (Fig. 5a). The total observed volume of water leachates $(181 \mathrm{~mm})$ was

318 underestimated by $34 \%$.

319 Step 1 led to a slight improvement in the simulation of the percolated volumes

320 when looking at the cumulative percolation over the whole period (Fig. 5b), with $E F$ of

3210.33 compared to 0.01 without ETP correction (Table 4). However, simulated volumes 
322 were strongly lower than the observed ones during Maize-1 period, especially from the

323 first important leaching event on 19 September 2011 (Fig. 5a). During the CC-2 period,

324 the percolated volumes were underestimated in the same way as in the absence of ETP

325 correction while during the second irrigated Maize-2 season, simulations were slightly

326 improved with the $k_{m}$ correction. However, for the CC-3 period after Maize-2 period,

327 the model largely overestimated the percolation volumes in fall 2012 (events between

328 October and December) (Fig. 5a).

After Step 2, MACRO simulated satisfactorily not only the total amount of water

330 leachates but also the individual leaching events (Fig. 5a, Table 4). The main 331 discrepancies between observations and simulations occurred during three periods: (1)

332 22 June - 25 July 2011, (2) 15 November 2011 - 16 January 2012, and (3) 8 August - 29

333 October 2012, when no leachate volume was collected in the lysimeter while MACRO 334 simulated some water percolation (Fig. 5a).

\subsection{Modelling S-metolachlor leaching}

On 22 May 2012, 19 days after its application, S-metolachlor was detected in the

338 leachate at $7.1 \mu \mathrm{g} \mathrm{L}^{-1}$ (Table 5). The high cumulated rainfall from 4 to 22 May 2012 339 (79.2 mm, Fig. 1) together with the high solubility in water of this herbicide could 340 explain this quick leaching. Since 22 May 2012, the herbicide concentration in the water

341 leachate decreased progressively until $0.08 \mu \mathrm{g} \mathrm{L}^{-1}$ on 17 December 2012 (last event of 342 measured leachate) (Table 5).

343 Because of the poor simulation of water flow without ETP correction, MACRO 344 was not able to model S-metolachlor transport at $1 \mathrm{~m}$ depth $(\mathrm{EF}<0)$ (Table 4). Except 345 for the latest drainage period, S-metolachlor concentrations and flows were largely 346 underestimated (Table 5). 
Step 1 did not improve the overall simulation of solute concentration and flow

348 (Tables 4 and 5). Concentrations were underestimated in the two first leaching periods and then were largely overestimated especially for the two latest leaching periods which occurred during the $\mathrm{CC}-3$ season. Conversely, water flows were underestimated during the two first events while they were overestimated during the three last ones (Table 5).

When using various $k_{m}$ values (Step 2), MACRO modelling of the herbicide concentrations and flows was improved $(E F=0.47$ and 0.19 respectively, $C R M=-0.38$ and -0.42 respectively, $r=0.82$ and 0.65 respectively) (Tables 4 and 5). The negative $C R M$ value shows that the model tends to overestimate the herbicide concentrations and flows, but it is mainly due to the marked overestimation of S-metolachlor concentration and flow measured in the 6-17 December 2012 period when MACRO overestimated the herbicide concentrations by factor of 53 and 285, respectively (Table 5). Contrary to the observations, the simulated S-metolachlor concentrations did not show a clear trend.

MACRO underestimated the herbicide concentrations in the 26 April - 22 May 2012 period, but they were generally overestimated (23 May - 17 December 2012). However,

362 it has to be underlined that, most of the time, simulated and measured concentrations 363 were in the same order of magnitude (Table 5).

\section{Discussion}

\subsection{Accounting for the effects of mulch of crop residues on water and pesticide flows}

Without correction of evapotranspiration, MACRO was not able to simulate the variations of soil water content measured in the soil profile when both a mulch of crop residues and a cover crop were introduced in the maize monoculture. Surprisingly, soil temperature simulations were quite good without any correction probably because the model simulated only small differences of temperature $\left(<1^{\circ} \mathrm{C}\right)$ at the time scale and 
372 depths considered when the mulch layer was or not included in the soil profile (data not

373 shown). Using different $k_{m}$ values had no effect on soil temperature simulation (Fig. 3).

374 In the second series of simulations, we first only considered (Step 1) the effect of

375 the crop residues mulch on the evapotranspiration during the maize growing season,

376 because the presence of crop residues on soil surface is known to decrease ETP

377 (Findeling et al., 2001; Khaledian et al., 2009). No ETP modification was done during

378 the cover crop growing season. In these conditions, the simulations of soil water content

379 and percolation volumes were improved, for instance that of the soil water content at 0.2

380 m depth, which was under the direct influence of the crop residues. However, we were

381 not able to satisfactorily simulate the dynamic of water percolation neither the S-

382 metolachlor flow during the whole period. Consequently, in a second step (Step 2), we

383 optimized the ETP correction choosing two $k_{m}$ values for each maize cropping period

384 (Fig. 2). We assumed that the reduction of the ETP depends on the mulch layer

385 thickness and coverage and on the decomposition of crop residues (Findeling et al.,

386 2007; Khaledian et al., 2009). Two different $k_{m}$ paired values had to be defined for 2011

387 (Maize-1) and 2012 (Maize-2). In 2011, an optimized $k_{m}=0.77$ was used from the first

388 cover crop destruction (5 April 2011) to the beginning of the irrigation period of the

389 Maize-1 (18 May 2011). In 2012, a $k_{m}=0.39$ was used from the second cover crop

390 destruction (15 March 2012) to the beginning of the irrigation period of the Maize-2 (20

391 June 2012). This low $k_{m}$ value was half the value used for the analogous period in 2011

$392\left(k_{m}=0.77\right)$. This is consistent with the higher amount of crop residues on the soil surface

393 after the cover crop destruction in $2012\left(5.3 \pm 0.9 \mathrm{t}\right.$ dry matter ha ${ }^{-1}$, more than $50 \%$ of

394 soil surface was covered by the crop residues) than in $2011\left(1.0 \pm 0.4 \mathrm{t}\right.$ dry matter $\mathrm{ha}^{-1}$,

$39525-35 \%$ of soil surface was covered by the crop residues) and with the findings of

396 Khaledian et al. (2009). In our study, the high percentage of soil surface covered by the 
crop residues in 2012 could have partially inhibited the development of the maize, as

398 evidenced by the lower maize grain yield obtained in $2012\left(7.5 \mathrm{t} \mathrm{ha}^{-1}\right)$ than in 2011

399 (10.0 $\left.\mathrm{t} \mathrm{ha}^{-1}\right)$, which could explain the decrease in the ETP. Some authors have also

400

401

402

403

404

405

observed a decrease in the emergence rate or a delay in the development of the main crop in presence of a mulch layer, which reduced the yield compared to conventional tillage (Chen et al., 2007; Khaledian et al., 2012, 2009).

For the two irrigation periods, from the starting of the irrigation to the emergence date of the following cover crops, we used $k_{m}=0.80$ and $k_{m}=0.92$ in 2011 and 2012 respectively (Fig. 2). During the Maize-2 season, the strong change of $k_{m}$ from 0.39 to 0.92 might be explained by the effect of mulch decomposition and by the climatic conditions. The average air temperature recorded for this period was lower in $2011\left(19.7^{\circ} \mathrm{C}\right)$ than in $2012\left(21.7^{\circ} \mathrm{C}\right)$, and the amount of rain plus irrigation was lower in $2011\left(3.0 \mathrm{~mm} \mathrm{~d}^{-1}\right)$ than in $2012\left(3.3 \mathrm{~mm} \mathrm{~d}^{-1}\right)$. This supports the different corresponding $k_{m}$ values $\left(k_{m}=0.80\right.$ in 2011 and $k_{m}=0.92$ in 2012). In a study carried out in maize fields under different water management practices, Liu et al. (2010) also observed that the experiment with supplementary irrigation showed the highest cumulative real evapotranspiration (ETR).

During the two maize crop cycles, the optimized $k_{m}$ values accounting for the crop residues effects on water balances considerably increased the quality of the simulation for both water and pesticide flow (Table 4). Step 2 involved a total decrease in ETR of $17 \%$ compared to the simulation that considered no $k_{m}$ value to determine the $\mathrm{ETP}_{\mathrm{m}}$. This percentage is within the experimental rate observed by Khaledian et al. (2012).

\subsection{Accounting for the effects of cover crop growth on water and pesticide flows}


The introduction of cover crops can considerably reduce water drainage and

423 pesticide flow in maize cropping systems (Alletto et al., 2012). When optimizing the $k_{m}$ 424 values for the cover crop growing season, $k_{m}$ was systematically kept to 1 which means that no ETP modification was necessary to simulate soil water content. Indeed, in the field, the cover crop grows in the presence of the maize crop residues during winter when evapotranspiration remains low. Consequently the effect of crop residues on ETP is negligible as was observed for CC-1 and CC-2.

However, for CC-3, both the soil water content and especially the water percolation were overestimated (Fig. 4, Table 5) leading to strong overestimation of the pesticide flow by MACRO. A higher ETP than that simulated would have been required

432 for this period. Though a decrease in the ETP due to the presence of a mulch layer on 433 the soil surface was frequently reported (Findeling, 2001; Khaledian et al., 2009), the opposite effect has been also observed (Shen et al., 2012). However, we chose to keep $k_{m}$ equal to 1 rather than using $k_{m}>1$ during the CC-3 period because evapotranspiration is usually low in winter period, as mentioned above. The discrepancies between observed and simulated data could also be related to progressive changes in soil hydraulic properties due to the adoption of conservation techniques and reduction of tillage in 2010. Such changes have been widely described in the literature (Green et al., 2003; Strudley et al., 2008) however they were not considered in our simulations. and cover crops on water balance and pesticide fate with MACRO, the introduction of a 443 correction factor for the ETP, which is the key determining factor, can be done 444 according to the following rules: (1) $k_{m}<1$ and decreases when the amount of crop 445 residues on soil surface and the surface cover increase, and (2) $k_{m}$ depends on the degree 446 of crop residue decomposition. 


\section{Conclusions}

Accounting for the combined effect of crop residue mulch and cover crops is critical to correctly simulate water balance and pesticide fate in conservation tillage systems. We tentatively used the MACRO model to simulate S-metolachlor herbicide leaching in an irrigated maize monoculture with intermediate cover crops. simulated considering the mulch as a high organic soil layer with its own hydraulic properties, and pesticide adsorption and degradation coefficients, while the effect of the crop residues on the water balance was taken into account by applying a correction factor $\left(k_{m}\right)$ to the ETP. Adjusting this empiric correction factor through a calibration exercise and according to observable criteria such as mulch thickness, soil coverage and plant residue decomposition improved the results of the simulations. The used parameterization allowed acceptable prediction of the field observations of water percolation and herbicide leaching although the performance of MACRO to simulate the soil water content was poorer. Though the possible effects of crop residues on soil temperature were not considered, the model predicted well the observed temperatures. This parameterization remains however limited to this case study and cannot be proposed for a predictive use of the model. Therefore, this approach needs to be tested against other soil-chemicals-crops-mulch combinations to be able to use the model as predictive tool.

Considering the importance of conservation tillage in today agricultural practices and the current limits pointed out by our study, despite the approach was developed

470 following an "ideal path" (Lahtinen et al., 2017), there is a need to improve pesticide 471 fate models used for risk assessment for pesticide registration at the European level in 
472 such cropping systems. A first option would be to include in MACRO a module

473 allowing to parameterize different $k_{m}$ values according to the above-mentioned criteria 474 and also to the type of crop residues. Another possibility would be to develop in such

475 models, a specific module able to simulate the different processes occurring within the 476 mulch layer and at the soil interface, and to account for different retroactions between 477 mulch decomposition, water balance and pesticide fate and transport.

478

479 Acknowledgements

480 JM Marín-Benito benefited from a post-doctoral contract through the ECoPESt project 481 that is supported by the Pesticides research program "Assessing and reducing 482 environmental risks from plant protection products" of the French Ministry in charge of 483 Ecology founded by the ECOPHYTO plan managed by ONEMA. The authors are very 484 grateful to Julien Moeys, Mats Larsbo and Nick Jarvis (Swedish University of 485 Agricultural Sciences) for providing the unofficial release of MACRO 5.3. The authors 486 thank Simon Giuliano (INP-EI Purpan) for his collaboration with the field data.

487

$488 \quad$ References

489 Abu-Awwad, A.M., 1999. Irrigation water management for efficient water use in 490 mulched onion. J. Agron. Crop Sci. 183, 1-7.

491 Alletto, L., Benoit, P., Bolognési, B., Couffignal, M., Bergheaud, V., Dumény, V., 492 Longueval, C., Barriuso, E., 2013. Sorption and mineralisation of S-metolachlor in 493 soils from fields cultivated with different conservation tillage systems. Soil Till. $494 \quad$ Res. 128, 97-103. 
495 Alletto, L., Benoit, P., Justes, E., Coquet, Y., 2012. Tillage and fallow period management effects on the fate of the herbicide isoxaflutole in an irrigated continuous-maize field. Agr. Ecosyst. Environ. 153, 40-49.

Alletto, L., Coquet, Y., Benoit, P., Heddadj, D., Barriuso, E., 2010. Tillage management effects on pesticide fate in soils. A Review. Agron. Sustain. Dev. 30, 367-400.

500 Alletto, L., Coquet, Y., Justes, E., 2011. Effects of tillage and fallow period 501 management on soil physical behavior and maize development. Agric. Water Manag. 102, 74- 85.

Aslam, S., Garnier, P., Rumpel, C., Parent, S.E., Benoit, P., 2013. Adsorption and desorption behavior of selected pesticides as influenced by decomposition of maize mulch. Chemosphere 91, 1447-1455.

Bedos, C., Alletto, L., Durand, B., Fanucci, O., Brut, A., Bourdat-Deschamps, M., 507 Giuliano, S., Loubet, B., Ceschia, E., Benoit, P., 2017. Observed volatilization fluxes of S-metolachlor applied on a bare soil and on soil covered by crop residues.

510 Beulke, S., Renaud, F., Brown, C.D., 2002. Development of guidance on parameter 511 estimation for the preferential flow model MACRO 4.2. Final Report of the DEFRA project PL0538. Cranfield Centre for EcoChemistry (University of Cranfield, UK), contract No. JA3749E; 68 pp.

514 Brisson, N., Launay, M., Mary, B., Beaudoin, N., 2009. Conceptual Basis, 515 Formalisations and Parameterization of the STICS Crop Model. Quæ, Versailles.

516 Bussière, F., Cellier, P., 1994. Modification of the soil temperature and water content 517 regimes by a crop residue mulch: experiment and modelling. Agric. For. Meteorol. $518 \quad 68,1-28$. 
519 Cassigneul, A., Alletto, L., Benoit, P., Bergheaud, V., Etiévant, V., Dumény, V., Le

520 Gac, A.L., Chuette, D., Rumpel, C., Justes, E., 2015. Nature and decomposition 521 degree of cover crops influence pesticide sorption: Quantification and modelling. $522 \quad$ Chemosphere 119, 1007-1014.

523 Cassigneul, A., Benoit, P., Bergheaud, V., Dumeny, V., Etiévant, V., Goubard, Y., 524 Maylin, A., Justes, E., Alletto, L., 2016. Fate of glyphosate and degradates in cover crop residues and underlying soil: A laboratory study. Sci. Total Environ. 545-546, $582-590$.

Castellanos-Navarrete, A., Rodriguez-Aragones, C., de Goede, R.G.M., Kooistra, M.J., Sayre, K.D., Brussaard, L., Pulleman, M.M., 2012. Earthworm activity and soil structural changes under conservation agriculture in central Mexico. Soil Till. Res. $123,61-70$.

Chen, S.Y., Zhang, X.Y., Pei, D., Sun, H.Y., Chen, S.L., 2007. Effects of straw mulching on soil temperature, evaporation and yield of winter wheat: field experiments on the North China plain. Ann. Appl. Biol. 150, 261-268.

Dahiya, R., Ingwersen, J., Streck, T., 2007. The effect of mulching and tillage on the water and temperature regimes of a loess soil: Experimental findings and modeling. Soil Till. Res. 96, 52-63.

Findeling, A., 2001. Etude et modélisation de certains effets du semis direct avec paillis de résidus sur les bilans hydrique, thermique et azoté d'une culture de maïs pluvial au Mexique. Thèse de doctorat en science de l'eau, École Nationale du Génie Rural des Eaux et des Forêts, Montpellier, 355 pp.

Findeling, A., Garnier, P., Coppens, F., Lafolie, F., Recous, S., 2007. Modelling water, Sci. 58, 196-206. 
544 FOCUS, 2000. Focus groundwater scenarios in the EU review of active substances.

545 Report of the FOCUS Groundwater Scenarios Workgroup, EC document reference $546 \quad$ Sanco/321/2000 rev.2, 202 pp.

547 Gan, J., Zhu, Y., Wilen, C., Pittenger, D., Crowley, D., 2003. Effect of planting covers 548 on herbicide persistence in landscape soils. Environ. Sci. Technol. 37, 2775-2779.

549 Garnier, P., Ezzine, N., De Gryze, S., Richard, G., 2004. Hydraulic properties of soil$550 \quad$ straw mixtures. Vadose Zone J. 3, 714-721.

551 Ghirardello, D., Morselli, M., Semplice, M., Di Guardo, A., 2010. A dynamic model of 552 the fate of organic chemicals in a multilayered air/soil system: Development and 553 illustrative application. Environ. Sci. Technol. 44, 9010-9017.

554 Green, T.R., Ahuja, L.R., Benjamin, J.G., 2003. Advances and challenges in predicting 555 agricultural management effects on soil hydraulic properties. Geoderma 116, 3-27.

556 Hartwig, N.L., Ammon, H.U., 2002. Cover crops and living mulches. Weed Sci. 50, $557 \quad 688-699$.

558 Iqbal, A., Beaugrand, J., Garnier, P., Recous, S., 2013. Tissue density determines the $559 \quad$ water storage characteristics of crop residues. Plant Soil 367, 285-299.

560 IUSS Working Group WRB, 2007. World Reference Base for Soil Resources 2006, first update 2007. World Soil Resources Reports No. 103. FAO, Rome.

562 Khaledian, M.R., Mailhol, J.C., Ruelle, P., Mubarak, I., 2012. Impacts of direct seeding 563 into mulch on the yield, water use efficiency and nitrogen dynamics of corn, 564 sorghum and durum wheat. Irrig. Drain. 61, 398-409.

565 Khaledian, M.R., Mailhol, J.C., Ruelle, P., Rosique, P., 2009. Adapting PILOTE model 566 for water and yield management under direct seeding system: The case of corn and 567 durum wheat in a Mediterranean context. Agric. Water Manag. 96, 757-770. 
Lahtinen, T.J., Guillaume, J.H.A, Hämäläinen, R.P., 2017. Why pay attention to paths

569 in the practice of environmental modelling? Environ. Model. Softw. 92, 74-81.

570 Lammoglia, S.K., Moeys, J., Barriuso, E., Larsbo, M., Marín-Benito, J.M., Justes, E.,

571 Alletto, L., Ubertosi, M., Nicolardot, B., Munier-Jolain, N., Mamy, L., 2017.

572 Sequential use of the STICS crop model and the MACRO pesticide fate model to

573 simulate pesticides leaching in cropping systems. Environ. Sci. Pollut. R. 24, 6895-

$574 \quad 6909$.

575 Larsbo, M., Jarvis, N.J., 2003. MACRO 5.0. A model of water flow and solute transport

576 in macroporous soil. Technical description. Rep Emergo, Swedish University of

$577 \quad$ Agricultural Sciences, Uppsala, Sweden, 49 pp.

578 Lascano, R.J., Baumhardt, R.L., 1996. Effects of Crop Residue on Soil and Plant Water

579 Evaporation in a Dryland Cotton System. Theor. Appl. Climatol. 54, 69-84.

580 Li, Q.Q., Chen, Y.H., Liu, M.Y., Zhou, X.B., Yu, S.L., Dong, B.D., 2008. Effects of

581 irrigation and straw mulching on microclimate characteristics and water use

582 efficiency of winter wheat in North China. Plant Prod. Sci. 11, 161-170.

583 Liu, Y., Li, S.Q., Chen, F., Yang, S.J., Chen, X.P., 2010. Soil water dynamics and water

584 use efficiency in spring maize (Zea mays L.) fields subjected to different water

585 management practices on the Loess Plateau, China. Agric. Water Manag. 97, 769-

$586 \quad 775$.

587 Marín-Benito, J.M., Pot, V., Alletto, L., Mamy, L., Bedos, C., Barriuso, E., Benoit, P.,

588 2014. Comparison of three pesticides fate models with respect to the leaching of two

589 herbicides under field conditions in an irrigated maize cropping system. Sci. Total $590 \quad$ Environ. 499, 533-545.

591 Martins, D., Goncalves, C.G., da Silva, A.C., 2016. Winter mulches and chemical 592 control on weeds in maize. Rev. Ciênc. Agron. 47, 649-657. 
593 Moeys, J., Larsbo, M., Bergström, L., Brown, C.D., Coquet, Y., Jarvis, N.J., 2012.

$594 \quad$ Functional test of pedotransfer functions to predict water flow and solute transport 595 with the dual-permeability model MACRO. Hydrol. Earth Syst. Sci. 16, 2069-2083.

596 Mottes, C., Lesueur-Jannoyer, M., Le Bail, M., Malézieux, E., 2014. Pesticide transfer 597 models in crop and watershed systems: a review. Agron. Sustain. Dev. 34, 229-250.

598 Plaza-Bonilla, D., Nolot, J.M., Passot, S., Raffaillac, D., Justes, E., 2016. Grain legume599 based rotations managed under conventional tillage need cover crops to mitigate soil $600 \quad$ organic matter losses. Soil Till. Res. 156, 33-43.

601 Plaza-Bonilla, D., Nolot, J.M., Raffaillac, D., Justes, E., 2017. Innovative cropping 602 systems to reduce $\mathrm{N}$ inputs and maintain wheat yields by inserting grain legumes 603 and cover crops in southwestern France. Eur. J. Agron. 82, 331-341.

604 Prosdocimi, M., Jordán, A., Tarolli, P., Keesstra, S., Novara, A., Cerdà, A., 2016. The 605 immediate effectiveness of barley straw mulch in reducing soil erodibility and 606 surface runoff generation in Mediterranean vineyards. Sci. Total Environ. 547, 323607330.

608 Queyrel, W., Habets, F., Blanchoud, H., Ripoche, D., Launay, M., 2016. Pesticide fate 609 modelling in soils with the crop model STICS: feasibility for assessment of $610 \quad$ agricultural practices. Sci. Total Environ. 542, 787-802.

611 Rampoldi, E.A., Hang, S., Barriuso, E., 2011. The fate of glyphosate in crop residues. 612 Soil Sci. Soc. Am. J. 75, 553-559.

613 Shen, J.Y., Zhao, D.D., Han, H.F., Zhou, X.B., Li, Q.Q., 2012. Effects of straw 614 mulching on water consumption characteristics and yield of different types of 615 summer maize plants. Plant Soil Environ. 58, 161-166.

616 Simunek, J., van Genuchten, M.T., Sejna, M., 2005. The Hydrus-1D software package 617 for simulating one-dimensional movement of water, heat, and multiple solutes in 

Laboratory.

Singh, P.N., Mitchell, J.P., Wallender, W.W., 2011. Parameter optimization for predicting soil water movement under crop residue cover. T. ASABE 54, 2029-

Smith, J., Smith, P., Addiscott, T., 1996. Quantitative methods to evaluate and compare soil organic matter (SOM) models. NATO ASI Series 38, 181-199.

Strudley, M.W., Green, T.R., Ascough, J.C., 2008. Tillage effects on soil hydraulic properties in space and time: state of the science. Soil Till. Res. 99, 4-48.

Thierfelder, C., Mwila, M., Rusinamhodzi, L., 2013. Conservation agriculture in eastern and southern provinces of Zambia: Long-term effects on soil quality and maize productivity. Soil Till. Res.126, 246-258.

Trail, P., Abaye, O., Thomason, W.E., Thompson, T.L., Gueye, F., Diedhiou, I., Diatta, M.B., Faye, A., 2016. Evaluating intercropping (living cover) and mulching

Tribouillois, H., Cohan, J.P., Justes, E., 2016. Cover crop mixtures including legume produce ecosystem services of nitrate capture and green manuring: assessment combining experimentation and modelling. Plant Soil 401, 347-364. Documenting the pesticide processes module of the ARS RZWQM agroecosystem

640 Weber, J.B., Taylor, K.A., Wilkerson, G.G., 2006. Soil cover and tillage influenced 641 metolachlor mobility and dissipation in field lysimeters. Agron. J. 98, 19-25. 
642 Whang, J.M., Schomburg, C.J., Glotfelty, D.E., Taylor, A.W., 1993. Volatilization of 643 fonofos, chlorpyrifos, and atrazine from conventional and no-till surface soils in the 644 field. J. Environ. Qual. 22, 173-180.

645 Wösten, J.H.M., Lilly, A., Nemes, A., Le Bas, C., 1999. Development and use of a 646 database of hydraulic properties of European soils. Geoderma 90, 169-185.

647 Yagioka, A., Komatsuzaki, M., Kaneko, N., Ueno, H., 2015. Effect of no-tillage with 648 weed cover mulching versus conventional tillage on global warming potential and 649 nitrate leaching. Agr. Ecosyst. Environ. 200, 42-53.

650

651 


\section{Figure captions}

653

654 Fig. 1. Measured rainfall and irrigation in Toulouse (Southwest France) experimental 655 site from 10 July 2010 to 31 December 2012.

656

657 Fig. 2. Values of the ETP correction factor $k_{m}$ used for the different cropping periods, 658 with fixed correction (non-optimized) during the maize season or with a variable 659 correction adjusted (optimized) for each maize cycle.

660

661 Fig. 3. Observed and simulated (without the application of the ETP correction factor $k_{m}$, 662 and with non-optimized and optimized $k_{m}$ values) soil temperature at $0.2,0.5$ and $1 \mathrm{~m}$ 663 depth.

664

665 Fig. 4. Observed and simulated (without the application of the ETP correction factor $k_{m}$, 666 and with non-optimized and optimized $k_{m}$ values) soil water content at $0.2,0.5$ and $1 \mathrm{~m}$ 667 depth.

668

669 Fig. 5. Observed and simulated (without the application of the ETP correction factor $k_{m}$, 670 and with non-optimized and optimized $k_{m}$ values) water percolation per period (a) and 671 cumulated (b) at $1 \mathrm{~m}$ depth. 
Table 1. Soil and mulch physicochemical and hydraulic characteristics.

$$
\text { Depth (m) } \quad 0-0.05 \quad 0.05-0.15 \quad 0.15-0.35 \quad 0.35-0.65 \quad 0.65-2.05^{\mathrm{a}}
$$

Characteristic

\begin{tabular}{|c|c|c|c|c|c|}
\hline Clay (\%) & $0.00^{b}$ & 39.8 & 40.1 & 45.8 & 51.5 \\
\hline Silt (\%) & $0.00^{\mathrm{b}}$ & 47.2 & 45.3 & 42.2 & 38.2 \\
\hline Sand (\%) & $100^{\mathrm{b}}$ & 13.0 & 14.6 & 12.0 & 10.3 \\
\hline $\mathrm{OC}(\%)$ & $42.8^{c}$ & 1.40 & 1.16 & 0.88 & 0.60 \\
\hline $\mathrm{pH}\left(0.01 \mathrm{M} \mathrm{CaCl}_{2}\right)$ & $6.2^{d}$ & 7.2 & 7.4 & 7.8 & 8.3 \\
\hline Bulk density $\left(\mathrm{g} \mathrm{cm}^{-3}\right)$ & $0.12^{\mathrm{e}}$ & 1.48 & 1.41 & 1.54 & 1.63 \\
\hline$\theta_{\mathrm{r}}\left(\mathrm{m}^{3} \mathrm{~m}^{-3}\right)^{\mathrm{f}}$ & 0.01 & 0.01 & 0.01 & 0.01 & 0.01 \\
\hline$\theta_{\mathrm{s}}\left(\mathrm{m}^{3} \mathrm{~m}^{-3}\right)^{\mathrm{g}}$ & $0.766^{\mathrm{h}}$ & 0.420 & 0.445 & 0.385 & 0.382 \\
\hline$\alpha\left(\mathrm{cm}^{-1}\right)^{\mathrm{g}}$ & $0.013^{\mathrm{h}}$ & 0.022 & 0.026 & 0.018 & 0.014 \\
\hline$n(-)^{g}$ & $1.204^{\mathrm{h}}$ & 1.111 & 1.121 & 1.072 & 1.058 \\
\hline $\mathrm{K}_{\mathrm{sat}}\left(\mathrm{mm} \mathrm{h}^{-1}\right)$ & $3.3^{\mathrm{h}}$ & 98.7 & 126.0 & 44.2 & 14.5 \\
\hline $\operatorname{CTEN}(\mathrm{cm})^{\mathrm{f}}$ & 10 & 10 & 10 & 10 & 10 \\
\hline $\mathrm{K}_{\mathrm{b}}\left(\mathrm{mm} \mathrm{h}^{-1}\right)^{\mathrm{i}}$ & 0.289 & 0.289 & 0.303 & 0.229 & 0.179 \\
\hline$\theta_{b}\left(m^{3} m^{-3}\right)^{j}$ & 0.756 & 0.413 & 0.435 & 0.381 & 0.379 \\
\hline $\operatorname{ASCALE}(\mathrm{mm})^{\mathrm{i}}$ & 1 & 1 & 50 & 150 & 150 \\
\hline $\mathrm{ZN} \mathrm{(-)})^{\mathrm{k}}$ & 3 & 3 & 3 & 2 & 2 \\
\hline $\mathrm{ZM}(-)^{\mathrm{g}}$ & $0.400^{\mathrm{h}}$ & -4.321 & -3.947 & -4.548 & -4.830 \\
\hline$\theta_{\mathrm{WP}}\left(\mathrm{m}^{3} \mathrm{~m}^{-3}\right)^{\mathrm{j}}$ & 0.268 & 0.220 & 0.216 & 0.277 & 0.287 \\
\hline
\end{tabular}

Note: The parameters without exponent correspond to measured parameters

${ }^{a}$ Physicochemical and hydraulic characteristics measured or estimated for the horizon 0.65-1.05 $\mathrm{m}$ and also used to parameterize the horizon $1.05-2.05 \mathrm{~m}$

${ }^{\mathrm{b}}$ Mulch layer was parameterized as a virtual sandy soil layer

${ }^{\mathrm{c}}$ From Cassigneul et al. (2016)

${ }^{\mathrm{d}}$ From Rampoldi et al. (2011)

${ }^{\mathrm{e}}$ From Garnier et al. (2004) for wheat residues

${ }^{\mathrm{f}}$ Default value

${ }^{\mathrm{g}}$ Estimated by HYPRES pedotransfer functions (Wösten et al., 1999)

${ }^{\mathrm{h}}$ From Wösten et al. (1999) for an organic soil

${ }^{\mathrm{i}}$ Estimated using the pedotransfer functions included in MACRO 5.2

${ }^{\mathrm{j}}$ Calculated from the water retention curves

${ }^{\mathrm{k}}$ Estimated from Beulke et al. (2002) 
Table 2. Input parameters for crop development.

\begin{tabular}{|c|c|c|c|c|c|}
\hline Crop & Date & $\begin{array}{c}\text { Crop } \\
\text { development }\end{array}$ & $\begin{array}{c}\text { LAI } \\
\left(\mathrm{m}^{2} \mathrm{~m}^{-2}\right)^{\mathrm{b}}\end{array}$ & $\begin{array}{c}\text { Root } \\
\text { depth }(m){ }^{b}\end{array}$ & $\begin{array}{c}\text { Root } \\
\text { distribution }\end{array}$ \\
\hline Cover crops & $14 / 10 / 2010$ & Emergence & 0.01 & 0.01 & \multirow{3}{*}{0.67} \\
\hline \multirow[t]{2}{*}{$(\mathrm{CC}-1)$} & $04 / 04 / 2011$ & Flowering & 1.51 & 0.37 & \\
\hline & 05/04/2011 & Harvest $^{\mathrm{a}}$ & 1.51 & 0.37 & \\
\hline & $05 / 05 / 2011$ & Emergence & 0.01 & 0.01 & \multirow{3}{*}{0.60} \\
\hline \multirow[t]{2}{*}{ (Maize-1) } & $20 / 07 / 2011$ & Flowering & 3.29 & 0.80 & \\
\hline & $07 / 10 / 2011$ & Harvest & 3.29 & 0.80 & \\
\hline \multirow{3}{*}{$\begin{array}{l}\text { Cover crops } \\
(\mathrm{CC}-2)\end{array}$} & $20 / 10 / 2011$ & Emergence & 0.01 & 0.01 & \multirow{3}{*}{0.67} \\
\hline & $14 / 03 / 2012$ & Flowering & 0.94 & 0.19 & \\
\hline & $15 / 03 / 2012$ & Harvest $^{\mathrm{a}}$ & 0.94 & 0.19 & \\
\hline \multirow{3}{*}{$\begin{array}{l}\text { Maize } \\
\text { (Maize-2) }\end{array}$} & $28 / 04 / 2012$ & Emergence & 0.01 & 0.01 & \multirow{3}{*}{0.60} \\
\hline & $17 / 07 / 2012$ & Flowering & 3.29 & 0.80 & \\
\hline & $21 / 09 / 2012$ & Harvest & 3.29 & 0.80 & \\
\hline \multirow{3}{*}{$\begin{array}{l}\text { Cover crops } \\
(\mathrm{CC}-3)\end{array}$} & 08/10/2012 & Emergence & 0.01 & 0.01 & \multirow{3}{*}{0.67} \\
\hline & $24 / 04 / 2013$ & Flowering & 3.40 & 0.56 & \\
\hline & $25 / 04 / 2013$ & Harvest $^{\mathrm{a}}$ & 3.40 & 0.56 & \\
\hline
\end{tabular}

\footnotetext{
${ }^{\mathrm{a}}$ The cover crops (oat+phacelia+vetch) destruction date was considered as harvest date.

${ }^{\mathrm{b}}$ From FOCUS (2000) for cover crops (considered as winter cereals) in Châteaudun scenario, and from Marín-Benito et al. (2014) for maize crop.

${ }^{\mathrm{c}}$ Fraction of root density in the uppermost $25 \%$ of the root depth.
} 
Table 3. Sorption coefficients $\left(\mathrm{K}_{\mathrm{d}}\right)$ and half-lives $\left(\mathrm{DT}_{50}\right)$ of S-metolachlor in the mulch and in the soil profile.

\begin{tabular}{lcc}
\hline \multirow{2}{*}{ Depth $(\mathrm{m})$} & \multicolumn{2}{c}{ S-metolachlor } \\
& $\mathrm{K}_{\mathrm{d}}\left(\mathrm{cm}^{3} \mathrm{~g}^{-1}\right)$ & $\mathrm{DT}_{50}(\mathrm{~d})$ \\
\hline $0-0.05($ mulch$)$ & $25.45^{\mathrm{a}}$ & $61.5^{\mathrm{b}}$ \\
$0.05-0.15$ & $1.9^{\mathrm{c}}$ & $57^{\mathrm{d}, \mathrm{e}}$ \\
$0.15-0.35$ & 1.58 & 57 \\
$0.35-0.65$ & 1.2 & 105 \\
$0.65-1.05$ & 0.482 & 169 \\
$1.05-2.05$ & 0.482 & n.d. ${ }^{\mathrm{f}}$ \\
\hline
\end{tabular}

${ }^{\text {a }}$ Estimated from $\mathrm{K}_{\mathrm{d} \text { soil }}=1.9 \mathrm{~L} \mathrm{~kg}^{-1}$ and $\mathrm{K}_{\mathrm{d} \text { mulch }}=49 \mathrm{~L} \mathrm{~kg}^{-1}$ and taking into account that $50 \%$ of the soil surface was covered by mulch after harvest.

${ }^{\mathrm{b}}$ Estimated from $\mathrm{DT}_{50 \text { soil }}=57 \mathrm{~d}$ and $\mathrm{DT}_{50}$ soil+mulch $=66 \mathrm{~d}$ and taking into account that $50 \%$ of the soil surface was covered by mulch after harvest.

${ }^{\mathrm{c}}$ From laboratory experiments. Values for deeper soil layers were estimated assuming sorption coefficients are proportional to organic carbon content.

${ }^{\mathrm{d}}$ From laboratory experiments with the same field soil.

${ }^{\mathrm{e}}$ Variation of the degradation rate $\mathrm{k}\left(\mathrm{k}\left(\mathrm{d}^{-1}\right)=\ln (2) / \mathrm{DT}_{50}\right)$ with depth: $\mathrm{k}$ for $0.05-$ $0.35 \mathrm{~m}, \mathrm{k} \times 0.5$ for $0.35-0.65 \mathrm{~m}, \mathrm{k} \times 0.3$ for $0.65-1.05 \mathrm{~m}, \mathrm{k}=0$ for $>1.0 \mathrm{~m}$ (FOCUS, 2000).

${ }^{\mathrm{f}}$ n.d.= no degradation. 
Table 4. Modelling efficiency $(E F)$, coefficient of residual mass $(C R M)$ and sample coefficient correlation $(r)$ of MACRO for the soil water content $(\theta)$ and temperature $(\mathrm{T})$ at $0.2,0.5$ and $1 \mathrm{~m}$ depth, and for the percolation and solute leaching at $1 \mathrm{~m}$ depth (with and without considering the ETP correction factor $k_{m}$ ).

\begin{tabular}{|c|c|c|c|c|c|c|c|c|c|}
\hline \multirow[b]{2}{*}{ Output } & \multicolumn{3}{|c|}{$E F$} & \multicolumn{3}{|c|}{$C R M$} & \multicolumn{3}{|c|}{$r$} \\
\hline & $0.2 \mathrm{~m}$ & $0.5 \mathrm{~m}$ & $1 \mathrm{~m}$ & $0.2 \mathrm{~m}$ & $0.5 \mathrm{~m}$ & $1 \mathrm{~m}$ & $0.2 \mathrm{~m}$ & $0.5 \mathrm{~m}$ & $1 \mathrm{~m}$ \\
\hline & \multicolumn{9}{|c|}{ Without $k_{m}$ values } \\
\hline$\theta$ (whole period) & -0.55 & -0.24 & -0.18 & 0.07 & -0.02 & -0.02 & 0.19 & 0.26 & 0.20 \\
\hline$\theta$ (since $20 / 06 / 2012)$ & -2.05 & -0.84 & -0.15 & 0.14 & 0.02 & 0.01 & 0.55 & 0.35 & 0.30 \\
\hline $\mathrm{T}$ (whole period) & 0.91 & 0.95 & 0.94 & 0.01 & 0.00 & 0.00 & 0.90 & 0.98 & 0.97 \\
\hline Percolation & - & - & 0.39 & - & - & 0.29 & - & - & 0.64 \\
\hline Cumulative percolation & - & - & 0.01 & - & - & 0.81 & - & - & 0.91 \\
\hline Solute concentration & - & - & -0.62 & - & - & 0.83 & - & - & 0.14 \\
\hline \multirow[t]{2}{*}{ Solute flow } & - & - & -0.62 & - & - & 0.88 & - & - & 0.19 \\
\hline & \multicolumn{9}{|c|}{ With non-optimized $k_{m}$ values (step 1) } \\
\hline$\theta$ (whole period) & 0.21 & -0.33 & -0.44 & -0.01 & -0.06 & -0.05 & 0.50 & 0.61 & 0.61 \\
\hline$\theta$ (since $20 / 06 / 2012$ ) & 0.03 & -0.31 & -0.19 & 0.03 & -0.03 & -0.03 & 0.49 & 0.52 & 0.48 \\
\hline $\mathrm{T}$ (whole period) & 0.91 & 0.95 & 0.94 & 0.01 & 0.00 & 0.00 & 0.90 & 0.98 & 0.97 \\
\hline Percolation & - & - & 0.27 & - & - & 0.25 & - & - & 0.61 \\
\hline Cumulative percolation & - & - & 0.33 & - & - & 0.54 & - & - & 0.89 \\
\hline Solute concentration & - & - & -1.24 & - & - & 0.06 & - & - & 0.64 \\
\hline \multirow[t]{2}{*}{ Solute flow } & - & - & -1.14 & - & - & 0.19 & - & - & 0.59 \\
\hline & \multicolumn{9}{|c|}{ With optimized $k_{m}$ values (step 2) } \\
\hline$\theta$ (whole period) & -0.20 & -0.67 & -0.62 & -0.04 & -0.07 & -0.06 & 0.23 & 0.44 & 0.53 \\
\hline$\theta$ (since $20 / 06 / 2012$ ) & 0.21 & -0.20 & -0.03 & 0.03 & -0.03 & -0.03 & 0.58 & 0.58 & 0.61 \\
\hline $\mathrm{T}$ (whole period) & 0.91 & 0.95 & 0.94 & 0.01 & 0.00 & 0.00 & 0.90 & 0.98 & 0.97 \\
\hline Percolation & - & - & 0.65 & - & - & -0.08 & - & - & 0.83 \\
\hline Cumulative percolation & - & - & 0.96 & - & - & 0.01 & - & - & 0.99 \\
\hline Solute concentration & - & - & 0.47 & - & - & -0.38 & - & - & 0.82 \\
\hline Solute flow & - & - & 0.19 & - & - & -0.42 & - & - & 0.65 \\
\hline
\end{tabular}


Table 5. Observed and simulated mean concentrations and cumulative flows of S-metolachlor in the leachates collected at $1 \mathrm{~m}$ depth.

\begin{tabular}{|c|c|c|c|c|c|c|c|c|}
\hline \multirow[t]{3}{*}{ Period } & \multicolumn{4}{|c|}{ Mean concentrations $\left(\mu \mathrm{g} \mathrm{L}^{-1}\right)$} & \multicolumn{4}{|c|}{ Cumulative flows $\left(\mu \mathrm{g} \mathrm{m}^{-2}\right)$} \\
\hline & \multirow[t]{2}{*}{ Observed } & \multicolumn{3}{|c|}{ MACRO } & \multirow[t]{2}{*}{ Observed } & \multicolumn{3}{|c|}{ MACRO } \\
\hline & & $\begin{array}{c}\text { Without } \\
k_{m}\end{array}$ & $\begin{array}{c}\text { With non- } \\
\text { optimized } \\
k_{m} \\
\text { (step 1) }\end{array}$ & $\begin{array}{c}\text { With } \\
\text { optimized } \\
k_{m} \\
\text { (step 2) }\end{array}$ & & $\begin{array}{c}\text { Without } \\
k_{m}\end{array}$ & $\begin{array}{c}\text { With non- } \\
\text { optimized } \\
k_{m} \\
\text { (step 1) }\end{array}$ & $\begin{array}{c}\text { With } \\
\text { optimized } \\
k_{m} \\
\text { (step 2) }\end{array}$ \\
\hline \multicolumn{9}{|l|}{ Maize-2 } \\
\hline $26 / 04-22 / 05 / 2012$ & 7.10 & 0.04 & 0.46 & 5.14 & 172.8 & 0.166 & 3.083 & 160.1 \\
\hline $23 / 05-12 / 06 / 2012$ & 5.20 & 0.74 & 2.68 & 6.48 & 193.5 & 14.48 & 61.94 & 189.5 \\
\hline $17 / 07-07 / 08 / 2012$ & 2.30 & 0.00 & 4.83 & 4.80 & 61.49 & 0.000 & 97.25 & 98.18 \\
\hline \multicolumn{9}{|l|}{$\mathrm{CC}-3$} \\
\hline $30 / 10-05 / 12 / 2012$ & 0.64 & 0.25 & 1.42 & 1.17 & 12.04 & 2.720 & 50.38 & 39.22 \\
\hline $06 / 12-17 / 12 / 2012$ & 0.08 & 1.13 & 4.96 & 4.24 & 0.430 & 29.87 & 143.9 & 122.6 \\
\hline
\end{tabular}




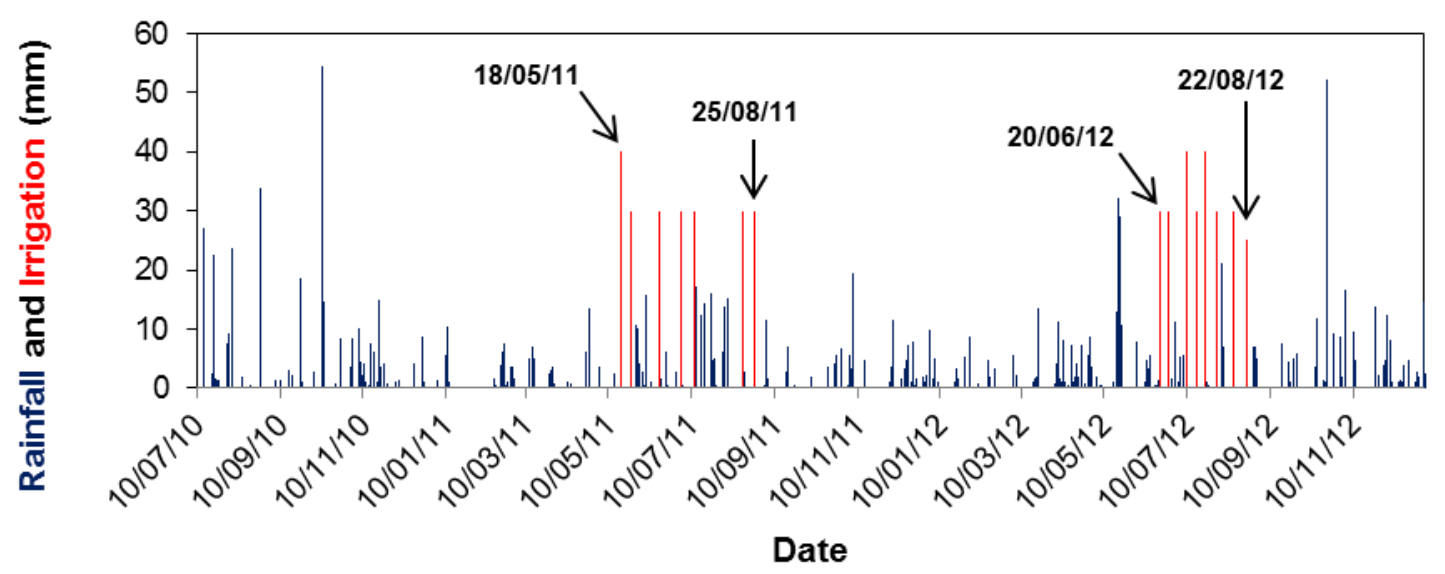

Fig. 1. Measured rainfall and irrigation in Toulouse (Southwest France) experimental site from 10 July 2010 to 31 December 2012. 


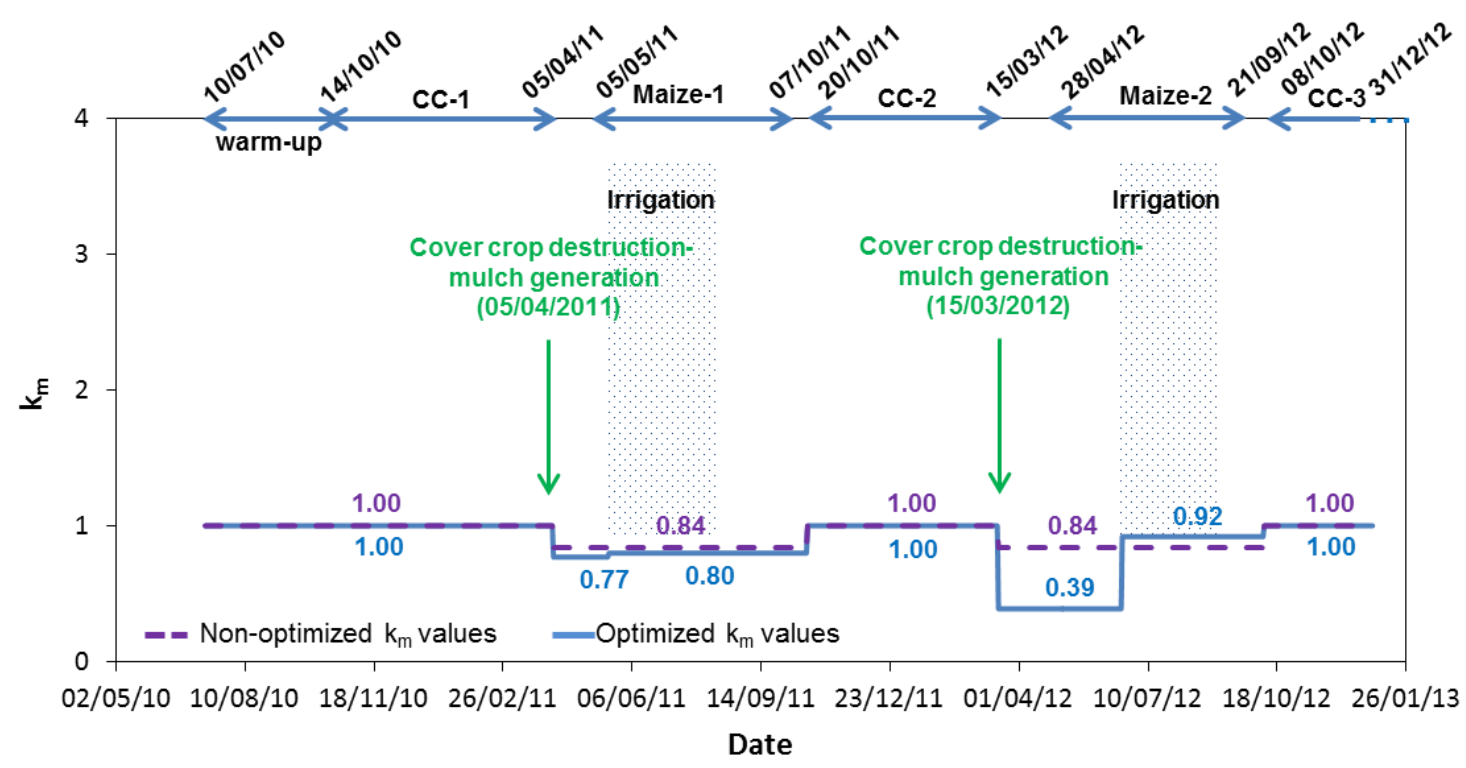

Fig. 2. Values of the evapotranspiration correction factor $k_{m}$ used for the different cropping periods, with fixed correction (non-optimized) during the maize season or with a variable correction adjusted (optimized) for each maize cycle. 

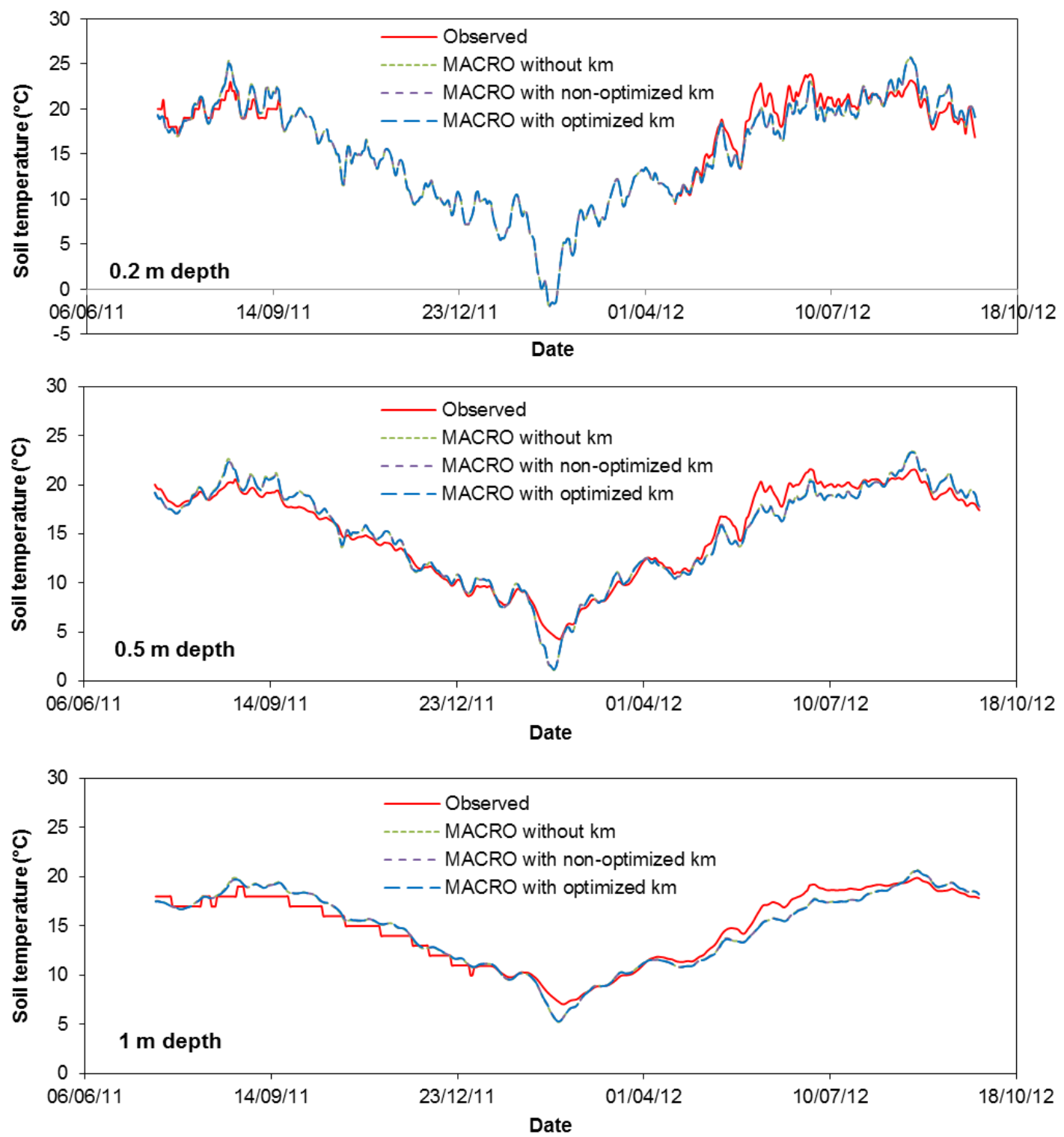

Fig. 3. Observed and simulated (without the application of the evapotranspiration correction factor $k_{m}$, and with non-optimized and optimized $k_{m}$ values) soil temperature at $0.2,0.5$ and $1 \mathrm{~m}$ depth. 

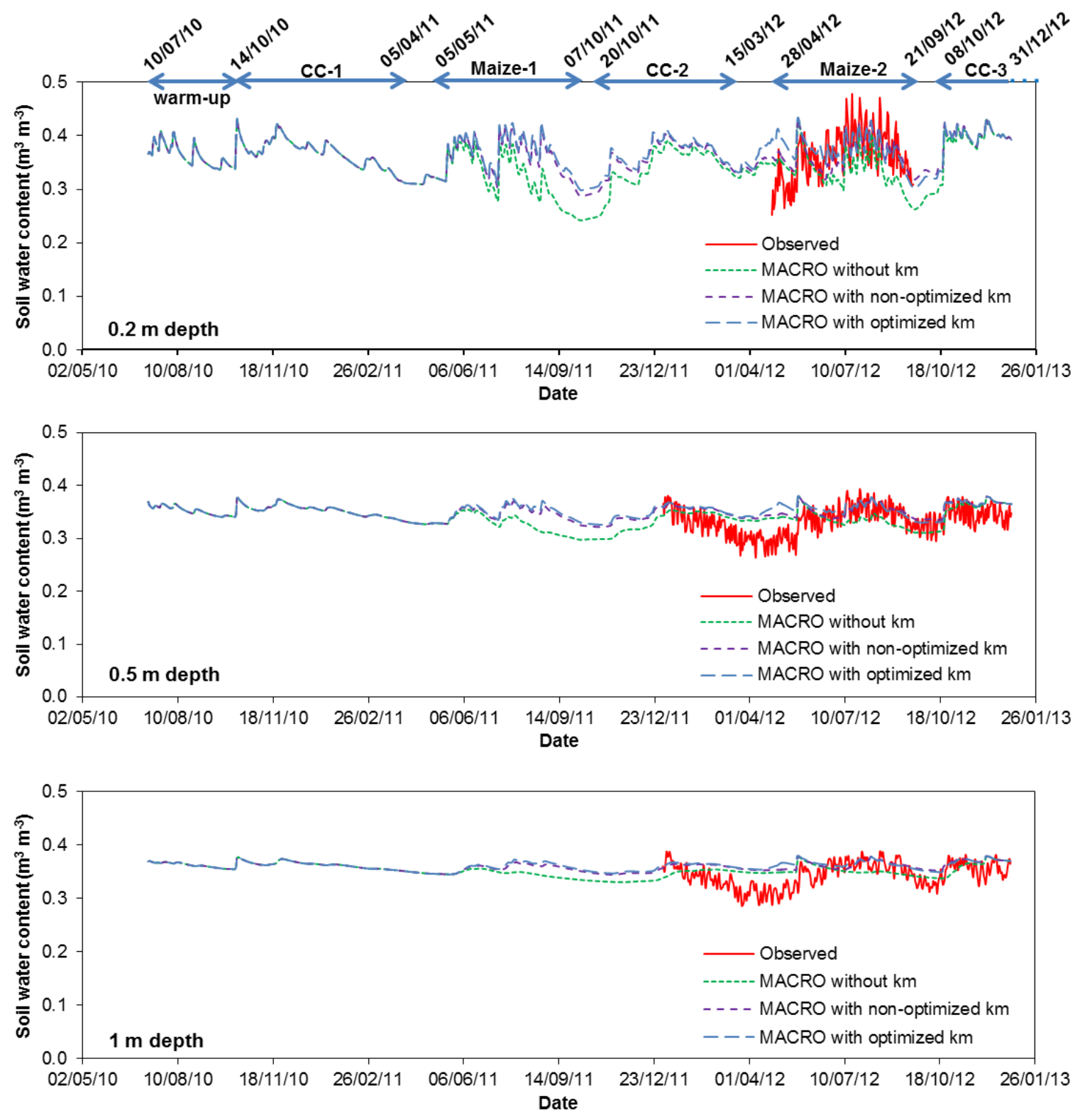

Fig. 4. Observed and simulated (without the application of the evapotranspiration correction factor $k_{m}$, and with non-optimized and optimized $k_{m}$ values) soil water content at $0.2,0.5$ and $1 \mathrm{~m}$ depth. 

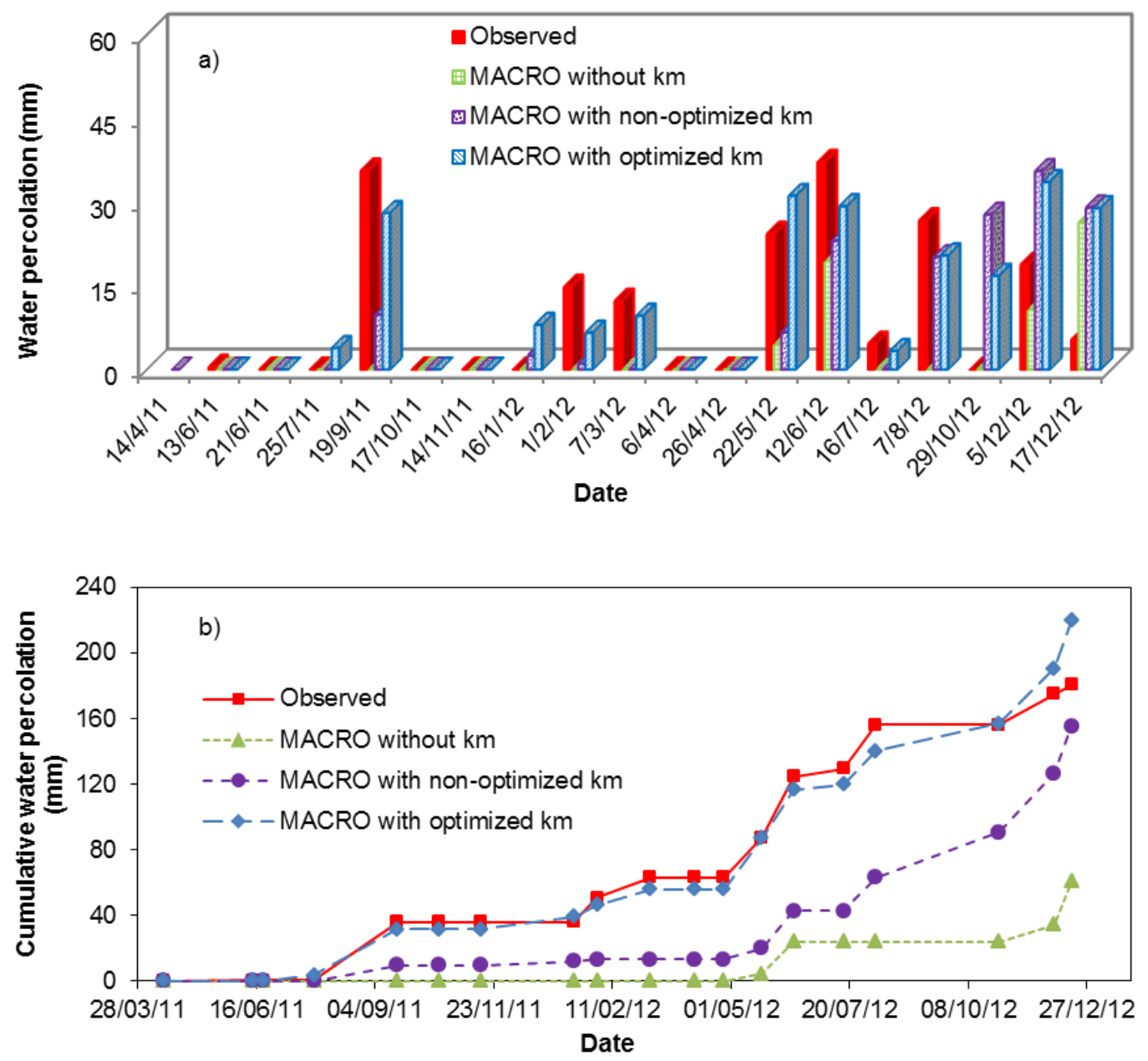

Fig. 5. Observed and simulated (without the application of the evapotranspiration correction factor $k_{m}$, and with non-optimized and optimized $k_{m}$ values) water percolation per period (a) and cumulated (b) at $1 \mathrm{~m}$ depth. 